\title{
The Diels-Alder reaction of 4-methoxy-7-hydroxyisobenzofuran with methyl vinyl ketone; a general method for identification of some regioisomeric $\alpha$-naphthols
}

\author{
B. A. KeAY AND R. RodRIGo' \\ Guelph-Waterloo Centre for Graduate Work in Chemistry, Department of Chemistry, University of Waterloo, \\ Waterloo, Ont., Canada N2L $3 G I$ \\ Received June 25, 1984
}

\begin{abstract}
B. A. KeAY and R. Rodrigo. Can. J. Chem. 63, 735 (1985).
Two regioisomeric $\alpha$-naphthols 14 and 15 obtained by aromatization of the methyl vinyl ketone adducts of an unsymmetrical isobenzofuran 9 are differentiated from each other by the observation of significant upfield shifts of the peri proton resonances in the ' $\mathrm{H}$ nmr spectra of their acetates $\mathbf{1 6}$ and 17. Such upfield shifts of $0.3-0.6 \mathrm{ppm}$ appear to be a general phenomenon and are probably due to the anisotropic effect of the acetate carbonyl group.
\end{abstract}

\section{B. A. KeAY et R. Rodrigo. Can. J. Chem. 63, 735 (1985).}

L'aromatisation des produits de la réaction de la méthylvinylcétone avec l'isobenzofuranne non-symétrique 9 conduit aux deux $\alpha$-naphtols régioisomères 14 et $\mathbf{1 5}$. On peut les différencier en faisant appel à la rmn du'H et aux glissements marqués vers les champs forts des résonances des protons péri de leurs acétates 16 et $\mathbf{1 7}$. Il semble que de tels glissements de 0,3 à $0,6 \mathrm{ppm}$ constituent un phénomène général et ils sont probablement dus à l'effet anisotropique du groupement carbonyle de l'acétate.

[Traduit par le journal]

In a recent publication ( 1 ) we described a short synthesis of the $\mathrm{AB}$ segment of daunomycinone 1 and its use in a convergent route to this anticancer antibiotic aglycone (for recent reviews, see ref. 2). Diels-Alder reaction of 4,7-dimethoxyisobenzofuran 2 (generated in situ (3) from the lactol 3) with methyl vinyl ketone (MVK) provided adduct 4 which suffered reverse-Michael cleavage (4) to the enone 5. The latter, suitably modified, was attached to the CD segment in a regiocontrolled annelation and eventually elaborated into the aglycone 1 .

In recent years a group of "second generation" anthracyclinones with reduced cardiotoxicity have been recognized. Prominent among these are aklavinone $(2,5)$ and some 11-deoxy analogues $(2,6)$ (e.g. 6) both of which lack the C-11 hydroxyl group and thus pose an additional regiochemical challenge to the synthetic chemist attempting to assemble these molecules from constituent fragments. To adapt our procedure to a synthesis of the $\mathrm{AB}$ half of such compounds it is necessary to differentiate the substituents at C-4 and C-7 of 2 and to control the regiochemistry of the Diels-Alder reaction of the unsymmetrical isobenzofuran thereby resulting.

Since the phthalide 7 was available for our earlier work (1), exploratory experiments were begun with this compound. Reduction of the carbonyl group with DIBAL-H provided the lactol 8 (70\% average yield) and Diels-Alder reaction of the unsymmetrical isobenzofuran 9 with MVK a mixture of regioisomeric adducts $\mathbf{1 0}$ and $\mathbf{1 1}$ in a 3.5:1 proportion by ${ }^{1} \mathrm{H} \mathrm{nmr}$ estimation (55\% total). Although some of the major isomer crystallized out from this mixture it was more convenient to subject the mixture to reverse-Michael cleavage (90\%) and separate the enones 12 (major) and 13 (minor) by column chromatography. These were isolated in the same ratio and individually dehydrated with dilute hydrochloric acid to naphthols 14 and 15 respectively, whose structures must now be unambiguously assigned. This paper describes a simple, general $\mathrm{H}$ nmr method for the differentiation of isomeric $\alpha$-naphthols like 14 and $\mathbf{1 5}$.

The spectra of $\mathbf{1 4}$ and $\mathbf{1 5}$ were very similar and unexceptional. In both compounds $\mathrm{H}-\mathrm{l}$ was a doublet, meta cou-

\footnotetext{
'Author to whom correspondence may be addressed.
}

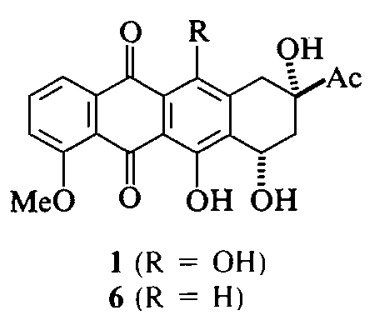<smiles>COc1ccc(O)c2c1C(=O)OC2</smiles><smiles>[R]Oc1ccc(O[R])c2c1COC2O</smiles>

$3\left(\mathrm{R}=\mathrm{R}^{\prime}=\mathrm{Me}\right)$ $8\left(\mathrm{R}=\mathrm{Me}, \mathrm{R}^{\prime}=\mathrm{H}\right)$

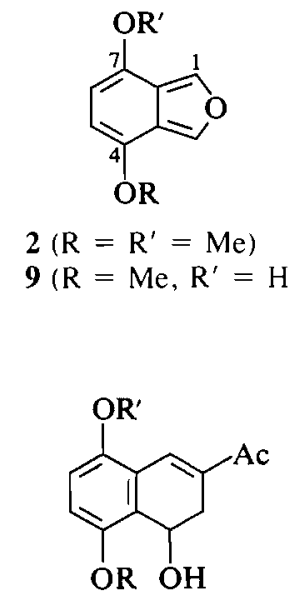

$5\left(\mathrm{R}=\mathrm{R}^{\prime}=\mathrm{Me}\right)$

$12\left(\mathrm{R}=\mathrm{Me}, \mathrm{R}^{\prime}=\mathrm{H}\right)$

$13\left(\mathrm{R}=\mathrm{H}, \mathrm{R}^{\prime}=\mathrm{Me}\right)$<smiles>[R]Oc1ccc(O)c2c(C)cc(C)c(C)c12</smiles>

$14\left(\mathrm{R}=\mathrm{Me}, \mathrm{R}^{\prime}=\mathrm{H}\right)$ $15\left(R=H, R^{\prime}=M e\right)$ $16\left(\mathrm{R}=\mathrm{Me}, \mathrm{R}^{\prime}=\mathrm{Ac}\right)$ $17\left(\mathrm{R}=\mathrm{Ac}, \mathrm{R}^{\prime}=\mathrm{Me}\right)$

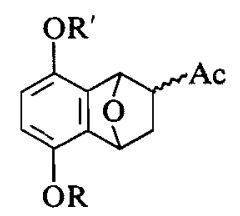

$$
\begin{aligned}
4(R & \left.=R^{\prime}=M e\right) \\
10(R & \left.=M e, R^{\prime}=H\right) \\
11(R & \left.=H, R^{\prime}=M e\right)
\end{aligned}
$$

pled to $\mathrm{H}-3\left(J_{1.3}=1.70\right.$ and $\left.1.76 \mathrm{~Hz}\right)$ at $8.82 \mathrm{ppm}$. Slight para coupling $\left(J_{1.4}=0.71 \mathrm{~Hz}\right)$ was observed in one isomer. A well-separated $\mathrm{AB}$ quartet $\left(J_{\mathrm{AB}}=9 \mathrm{~Hz}\right)$ was present with $\mathrm{H}-3$ at $8.0 \mathrm{ppm}$ and $\mathrm{H}-4$ at $8.26 \mathrm{ppm}$, assignments that are secured by the meta-coupling observed for $\mathrm{H}-3$. Slight differences in the absorptions of $\mathrm{H}-6, \mathrm{H}-7$, methoxy, and acetyl signals in the two isomers were not of any diagnostic value. Acetylation provided the $\alpha$-naphthyl acetates 16 and 17, respectively, with consequent changes in the spectra. New three-proton singlets at 2.43 and $2.50 \mathrm{ppm}$ and the expected downfield shifts of the aromatic proton ortho to the acetate (7) by ca. $0.3-0.4 \mathrm{ppm}$, in each case, signified the presence of the acetate moiety. The 
changes observed in the absorptions of $\mathrm{H}-1$ and $\mathrm{H}-4$ were of much greater significance to the problem at hand. In one acetate the meta-coupled doublet $(\mathrm{H}-1)$ was shifted upfield by 0.41 $\mathrm{ppm}(8.82 \rightarrow 8.41)$ while in the other one-half of the $\mathrm{AB}$ quartet ( $\mathrm{H}-3, \mathrm{H}-4)$ shifted upfield again, this time by $0.32 \mathrm{ppm}$ $(8.26 \rightarrow 7.94)$. Assignment of this signal to $\mathrm{H}-4$ was supported by the lack of meta-coupling observed for the $\mathrm{H}-3$ half of the $\mathrm{AB}$ quartet $\left(J_{1.3}=1.46 \mathrm{~Hz}\right)$. Thus a tentative assignment of structure can be made as follows for the $\alpha$-naphthols and their acetates: acetate $\mathbf{1 6}$ is that regioisomer in which the $\mathrm{H}-1$ metacoupled doublet (proton peri to the acetate) shifts upfield by $0.41 \mathrm{ppm}$ in comparison to naphthol $\mathbf{1 4}$, and acetate $\mathbf{1 7}$ is the other isomer in which H-4 (proton peri to the acetate) shifts upfield by $0.32 \mathrm{ppm}$ in comparison to the parent naphthol 15 . Since naphthol 14 was obtained from the major isomer of the Diels-Alder adduct mixture this establishes the structure of adducts 10 (major) and 11 (major) and enones 12 (major) and 13 (minor) as shown. These conclusions received independent support from an X-ray structure determination ${ }^{2}$ of the major crystalline adduct $\mathbf{1 0}$.

These upfield acetylation shifts of the peri-proton of $\alpha$-naphthols were investigated in five more examples to determine whether this was a general phenomenon. In the first instance, naphthol 18 obtained by aromatization of a known (3) Diels-Alder adduct was converted to its acetate 19. Again, one of the aromatic singlets (at 7.19 and $7.67 \mathrm{ppm}$ in 18) was shifted upfield by $0.3 \mathrm{ppm}$ ( 7.18 and 7.37 in 19). The obvious question of whether this signal was due to $\mathrm{H}-1$ or $\mathrm{H}-4$ was answered by observation of a $20 \%$ nOe enhancement of the signal at $7.19 \mathrm{ppm}$ of $\mathbf{1 8}$ when the C-5 methyl resonance at 2.39 $\mathrm{ppm}$ was irradiated. A group of aryl substituted $\alpha$-naphthols (8) $(\mathbf{2 0}, \mathbf{2 2}, \mathbf{2 4}$, and 26) was examined next. In these compounds the two aromatic protons at $\mathrm{C}-1$ and $\mathrm{C}-4$ are easily differentiated because $\mathrm{H}-4$, subjected to the shielding influence of
TABLE I. Chemical shifts of peri-protons in $\alpha$-naphthols and their acetates

\begin{tabular}{cccccc}
\hline \hline \multicolumn{2}{c}{ Compound } & & \multicolumn{2}{c}{ peri-Proton, $\mathrm{H}-1(\delta) \mathrm{ppm}$} & \\
\cline { 1 - 2 } $\boldsymbol{\alpha}$-Naphthol & Acetate & & $\alpha$-Naphthol & Acetate & $\Delta \delta(\mathrm{ppm})$ \\
\hline $\mathbf{1 4}$ & $\mathbf{1 6}$ & & 8.82 & 8.41 & -0.41 \\
$\mathbf{1 5}$ & $\mathbf{1 7}$ & & 8.26 & 7.94 & -0.32 \\
$\mathbf{1 8}$ & $\mathbf{1 9}$ & & 7.67 & 7.37 & -0.30 \\
$\mathbf{2 0}$ & $\mathbf{2 1}$ & & 7.74 & 7.22 & -0.52 \\
$\mathbf{2 2}$ & $\mathbf{2 3}$ & & 7.74 & 7.21 & -0.53 \\
$\mathbf{2 4}$ & $\mathbf{2 5}$ & & 7.74 & 7.21 & -0.53 \\
$\mathbf{2 6}$ & $\mathbf{2 7}$ & 7.74 & 7.16 & -0.58 \\
\hline
\end{tabular}

the pendant aryl ring (not coplanar with the naphthalene), always resonates at a higher field than $\mathrm{H}-\mathrm{l}$. Thus in all these naphthols $\mathrm{H}-\mathrm{l}$ appears as singlet at $7.74 \mathrm{ppm}$ and $\mathrm{H}-4$ at 6.81-6.89 ppm. Upon acetylation $\mathrm{H}-\mathrm{l}$ is observed to shift upfield by $0.52-0.58 \mathrm{ppm}$ while $\mathrm{H}-4$ is relatively unaffected. Thus in all seven examples we have studied, a substantial upfield shift of ca. $0.3-0.6 \mathrm{ppm}$ is observed in the peri-proton of an $\alpha$-naphthol upon acetylation (Table 1).

A recent X-ray structure (9) of the $\alpha$-naphthyl diacetate $\mathbf{2 8}$ indicates that the $\mathrm{O}-\mathrm{C}$ bond of the acetate is at an angle of $82.3^{\circ}$ to the plane of the naphthalene ring with the carbonyl double bond directed back over the ring as shown in Fig. 1. This diagram, generated ${ }^{3}$ from data reported in that paper, shows that in the crystal of $\mathbf{2 8}$ the peri-proton lies in the shielding zone of the acetate carbonyl group and is $2.45 \AA$ distant from the carbonyl oxygen atom. Progressively greater shielding of the peri-proton in a series of 1-acyl 4-methoxy naphthalenes 29 was observed (10) as the size of the group R is increased (from hydrogen to tert-butyl) and the suggestion made that the increasing bulkiness of the substituent forces the<smiles></smiles>

$20(\mathrm{R}=\mathrm{H}, \mathrm{Ar}=3,4,5$-trimethoxyphenyl $)$

21 ( $R=A c, A r=3,4,5$-trimethoxyphenyl)

$22(\mathrm{R}=\mathrm{H}, \mathrm{Ar}=3,4$-dimethoxyphenyl)

$23(\mathrm{R}=\mathrm{Ac}, \mathrm{Ar}=3,4$-dimethoxyphenyl)

$24(\mathrm{R}=\mathrm{H}, \mathrm{Ar}=3,4$-methylenedioxyphenyl)

$25(\mathrm{R}=\mathrm{Ac}, \mathrm{Ar}=3,4$-methylęnedioxyphenyl $)$

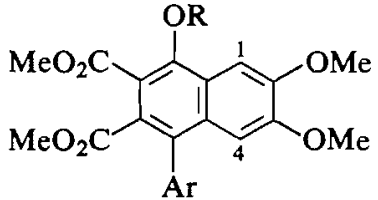

$26(\mathrm{R}=\mathrm{H}, \mathrm{Ar}=3,4$-methylenedioxyphenyl)

$27(\mathrm{R}=\mathrm{Ac}, \mathrm{Ar}=3,4$-methylenedioxyphenyl)

19 $(R=H)$

$18(\mathrm{R}=\mathrm{H})$<smiles>CCCCc1c(C(C)=O)c(C(C)=O)c(C)c2cc3c(cc12)OCO3</smiles><smiles>CC(=O)Oc1cc(Cl)c(Cl)cc1OC(C)=O</smiles>

28

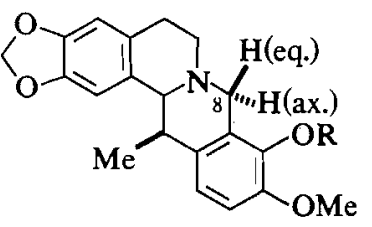<smiles>[R]C(=O)C1=CC=C(OC)C2C=CC=CC12</smiles>

29

$30(\mathrm{R}=\mathrm{H})$

$31(\mathrm{R}=\mathrm{Ac})$

\footnotetext{
${ }^{2}$ N. J. Taylor, B. A. Keay, and R. Rodrigo. Unpublished data.

${ }^{3}$ This computer generated diagram was prepared by Dr. N. J. Taylor of this department from the data reported in ref. 9 . We thank Dr. Taylor for his assistance.
} 


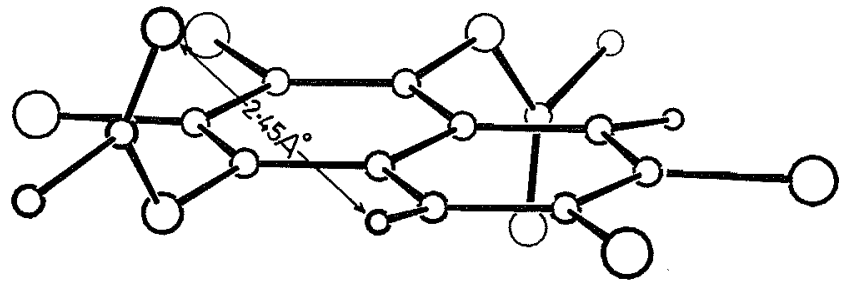

FIG. 1. The crystal structure of $\mathbf{2 8}$ (see footnote 3 ).

carbonyl group to adopt a conformation perpendicular to the plane of the naphthalene ring. This shielding effect is not confined to naphthalenes. It has been reported (11) that acetylation of the tetrahydroprotoberberine $\mathbf{3 0}$ causes unequal upfield shifts of the protons at C-8 of the resulting acetate 31 . The H-8 equatorial proton of this trans-quinolizidine (12) is shifted upfield by $0.2 \mathrm{ppm}$, while the $\mathrm{H}-8$ axial proton is only slightly affected $(\Delta \delta=-0.06 \mathrm{ppm}$ ) by acetylation. The inequality of the upfield shifts implies a dependence on geometry and supports the operation of an anisotropic effect. It has been convincingly demonstrated (13) that none of the simple theories of magnetic shielding provide acceptable quantitative predictions of the chemical shifts of all the protons in 1 -substituted naphthalenes, but the qualitative trends described in this paper might be of value in the assignment of structures to some $\alpha$-naphthols.

The 3.5:1 regioselectivity observed in the Diels-Alder reaction of 9 with MVK deserves a brief comment. Previous investigators have established that 1 -substituted isobenzofurans show a preference for "ortho" addition with unsymmetrical dienophiles $(4,14)$ which depends neither on the nature of the substituent nor on the dienophile. No studies exist of the influence of substituents on the regiochemistry of the reaction when such substituents are located on the cyclohexadiene ring (i.e. C4-C7 substituted isobenzofurans) except for one example where 4-methoxyisobenzofuran provided a 1:1 mixture of adducts with a quinone (15). The present example of differential substitution on this ring (the Diels-Alder reaction of 9 with MVK), and the regioselectivity observed therein, suggests that this may well be a fruitful area for further exploration. It is possible that the formation of the major adduct $\mathbf{1 0}$ is favoured by hydrogen bonding between the 7-hydroxy group of 8 and the carbonyl group of the dienophile in the endo transition state of the reaction. We are engaged in the preparation of 4- and 5-hydroxy and methoxy isobenzofurans and in the study of the Diels - Alder reactions of these dienes with unsymmetrical dienophiles. A meaningful discussion of the problem as well as further progress towards the 11-deoxy anthracyclinones will have to await the outcome of such work.

\section{Experimental}

Melting points were determined on a Buchi model SMP-20 apparatus and are uncorrected. Elemental analyses were performed by the Guelph Chemical Laboratories, Guelph, Ontario. Proton magnetic resonance spectra were determined, unless otherwise stated, in deuteriochloroform on a BrukerWP-80 spectrometer. Coupling constants were measured directly and confirmed by decoupling where necessary. Spectra are reported in the following manner: chemical shift $(\delta)$ in ppm (multiplicity, number of protons, assignment, coupling constants in $\mathrm{Hz}$ ). Infrared spectra were obtained on a Beckmann model IR 10 or Acculab 10 spectrophotometer in the manner specified in each case. Mass spectra were determined on a Varian VG 7070F instrument and are reported as follows: ion (relative intensity, assignment). Column chromatography was performed with silica gel (Merck,
$0.063-0.20 \mathrm{~mm}, 70-230$ mesh ASTM) in the specified solvent system.

4-Methoxy-1,3-dihydroisobenzofuran-3,7-diol 8

The phthalide 7 (ref. I) (0.25 g) dissolved in dry methylene chloride $(20 \mathrm{~mL})$ was cooled to $-60^{\circ} \mathrm{C}$ and diisobutyl aluminum hydride ( $3.5 \mathrm{~mL}$ of $25 \%$ solution in toluene) added. After stirring for $70 \mathrm{~min}$, aqueous sodium hydroxide $(7 \mathrm{~mL}, 10 \%)$ was added and the solution allowed to warm to room temperature. The methylene chloride was removed, water added, and carbon dioxide bubbled through until the solution was neutral. The aqueous mixture was extracted with ethyl acetate $(3 \times 10 \mathrm{~mL})$. The extracts were dried $\left(\mathrm{Na}_{2} \mathrm{SO}_{4}\right)$ and the solvent removed in vacuo at room temperature. The residue was crystallized from chloroform $(175 \mathrm{mg}, 70 \%)$, mp $113^{\circ} \mathrm{C}(\mathrm{dec}$ ); ir (KBr): $3250(\mathrm{br})$ $\mathrm{cm}^{-1}$; ' $\mathrm{H} \mathrm{nmr}$ (acetone- $\left.d_{6}\right): 3.76(\mathrm{~s}, 3 \mathrm{H}, \mathrm{OMe}), 4.81\left(\mathrm{~d}, 1 \mathrm{H}, J_{\mathrm{gctm}}=\right.$ 12.9. $>\mathrm{C} H-\mathrm{O}), 5.09\left(\mathrm{dd}, 1 \mathrm{H}, J_{x c m}=12.9, J_{1.3}\right.$ trans $=2.15$, $\mathrm{CH}-\mathrm{O}), 5.31\left(\mathrm{~d}, 1 \mathrm{H}, J=7.8\right.$ disappears with $\left.\mathrm{D}_{2} \mathrm{O}, \mathrm{OH}\right), 6.42$ (dd, $1 \mathrm{H}, J_{\mathrm{H} . \mathrm{OH}}=7.8,>J_{1.3}=2.15$, collapses to doublet with $\left.\mathrm{D}_{2} \mathrm{O}\right), 6.73$ (s, $2 \mathrm{H}, \mathrm{H}-5$ and $\mathrm{H}-6), 8.0\left(\mathrm{~s}, 1 \mathrm{H}\right.$, phenolic $\mathrm{H}$, disappears with $\mathrm{D}_{2} \mathrm{O}$ ); ms: $182\left(100, \mathrm{M}^{++}\right), 165\left(75, \mathrm{M}^{*+}-\mathrm{OH}\right), 164\left(68, \mathrm{M}^{++}-\mathrm{H}_{2} \mathrm{O}\right)$. Anal. calcd. for $\mathrm{C}_{9} \mathrm{H}_{10} \mathrm{O}_{4}$ : C 59.34, H 5.53; found: C 60.01, H 5.73.

\section{2-endo-Acetyl-5methoxy-8-hydroxy-1,4-epoxy-1,2,3,4-tetrahydro-} naphthalene 10

The hydroxyphthalan $8(240 \mathrm{mg})$ in carbon tetrachloride $(8 \mathrm{~mL})$ was refluxed for $19 \mathrm{~h}$ with glacial acetic acid $(0.5 \mathrm{~mL})$ and methyl vinyl ketone $(0.82 \mathrm{~mL})$. Aqueous sodium bicarbonate was added to neutralize the acid and the organic phase separated, dried $\left(\mathrm{Na}_{2} \mathrm{SO}_{4}\right)$, and the solvent removed. A ' $\mathrm{H}$ nmr spectrum of the residual oil showed the presence of the two regioisomers $\mathbf{1 0}$ and $\mathbf{1 1}$ in the ratio of ca. 3.5:1 and a third compound identified as 4-carbomethoxy-2-butanone $(2.0$ $(\mathrm{s}, 3 \mathrm{H}), 2.2(\mathrm{~s}, 3 \mathrm{H}), 2.78(\mathrm{t}, 2 \mathrm{H})$, and $4.35(\mathrm{t}, 2 \mathrm{H}))$ resulting from Michael addition of acetic acid to methyl vinyl ketone. The ratio of 10 to 11 in this mixture was estimated by comparison of the two proton aromatic singlets and methoxy singlets of $\mathbf{1 0}$ (at 6.62 and $3.78 \mathrm{ppm}$ ) and 11 (at 6.55 and $3.72 \mathrm{ppm}$ ). Column chromatography of the crude mixture (ethyl acetate - ligroin, 5:6) and removal of the solvents provided an oil (55\% yield) whose ${ }^{1} \mathrm{H} \mathrm{nmr}$ spectrum indicated the presence of 10 and 11 in the same ratio. Other absorptions of the minor regiosomer 11 were clearly discernible in this spectrum but were not separated sufficiently from the corresponding absorptions of $\mathbf{1 0}$ to be used for reliable ' $\mathrm{H}$ nmr estimation of the ratio. Crystals formed upon addition of benzene to the mixture (10/11) were separated, subjected to X-ray analysis, and found to be the endo-isomer of $\mathbf{1 0}$.

10 (endo-isomer); mp $153-155^{\circ} \mathrm{C}$; ir $(\mathrm{KBr}): 3300,1710 \mathrm{~cm}^{-1} ;{ }^{1} \mathrm{H}$ nmr: $1.67\left(\mathrm{dd}, \mathrm{IH}, \mathrm{H}-3 \alpha, J_{g c m}=11.4, J_{2.3 \mathrm{c}}=4.82\right), 2.11(\mathrm{~s}, 3 \mathrm{H}$, $\mathrm{COCH}_{3}$ ), 2.48 (ddd, $1 \mathrm{H} \mathrm{H}-3 \beta, J_{g c m}=11.4, J_{3 \beta .4}=3.5, J_{2.3 \beta}=$ 12.04 ), 3.42 (ddd, $1 \mathrm{H}, \mathrm{H}-2, J_{1.2}=3.9, J_{2.3 \beta}=12.04, J_{2.3 \alpha}=4.82$ ), $3.78(\mathrm{~s}, 3 \mathrm{H}, \mathrm{OMe}), 5.58\left(\mathrm{~d}, 1 \mathrm{H}, \mathrm{H}-4, J_{3 \beta .4}=3.5\right), 5.63(\mathrm{~d}, 1 \mathrm{H}, \mathrm{H}-\mathrm{I}$, $\left.J_{1.2}=3.9\right), 5.72\left(\mathrm{~s}, 1 \mathrm{H}, \mathrm{OH}\right.$, disappears with $\left.\mathrm{D}_{2} \mathrm{O}\right), 6.62(\mathrm{~s}, 2 \mathrm{H}, \mathrm{H}-6$ and $\mathrm{H}-7)$; ms: $234\left(17, \mathrm{M}^{-+}\right), 164\left(100, \mathrm{M}^{-+}-\mathrm{CH}_{3} \mathrm{COCH}=\mathrm{CH}_{2}\right.$ retro Diels-Alder). Anal. calcd. for $\mathrm{C}_{13} \mathrm{H}_{14} \mathrm{O}_{4}: \mathrm{C} 66.66, \mathrm{H} 6.02$; found: C 66.43, H 5.93.

\section{2-Acetyl-4,8-dihydroxy-5-methoxy-3,4-dihydronaphthalene 12 and}

2-acetyl-4,5-dihydroxy-8-methoxy-3,4-dihydronaphthalene 13

The mixture of adducts 10 and $11(600 \mathrm{mg})$ was suspended in dry methanol $(10 \mathrm{~mL})$ under a nitrogen atmosphere and cooled to $0^{\circ} \mathrm{C}$. Sodium methoxide $(0.5 \mathrm{~g}$ sodium in $10 \mathrm{~mL}$ of absolute methanol) was added slowly over $20 \mathrm{~min}$. The solution was warmed to room temperature and stirred for $4 \mathrm{~h}$. Water was added and carbon dioxide bubbled through until neutral to litmus. The solution was poured into saturated brine $(100 \mathrm{~mL})$ and extracted into chloroform $(5 \times 20 \mathrm{~mL})$. The extracts were dried $\left(\mathrm{Na}_{2} \mathrm{SO}_{4}\right)$ and the solvent removed in vacuo to leave a solid $(90 \%)$ which was chromatographed on a column of silica gel in ethyl acetate - ligroin $(8: 2)$ and the two regioisomers of

\footnotetext{
${ }^{4}$ The somewhat high result obtained for carbon may be due to the dehydration of some of the lactol during combustion. Its physical and chemical properties are consistent with several similar compounds prepared and studied earlier (ref. 3).
} 
12 and 13 obtained $^{5}$ in the ratio of ca. 3.5:1.

12; $R, 0.2 ; \mathrm{mp} 116-117^{\circ} \mathrm{C}$ (ether); ir (KBr): 3500,3310 (br), 1640 , $1620 \mathrm{~cm}^{-1} ;{ }^{1} \mathrm{H} \mathrm{nmr}$ (acetone- $\left.d_{6}\right): 2-2.4(\mathrm{~m}, \mathrm{IH}, \mathrm{H}-3 \beta), 2.40(\mathrm{~s}, 3 \mathrm{H}$, $\left.\mathrm{COCH}_{3}\right), 3.16\left(\mathrm{dd}, 1 \mathrm{H}, \mathrm{H}-3 \alpha, J_{\mathrm{gcm}}=18.2, J_{3(\alpha, 4}=2.0\right), 3.55(\mathrm{~d}, 1 \mathrm{H}$, C4-OH, $J=8.0$, disappears with $\mathrm{D}_{2} \mathrm{O}$ ), 3.80 (s, 3H, OMe), 5.20 (dd, after $\left.\mathrm{D}_{2} \mathrm{O}, 1 \mathrm{H}, \mathrm{H}-4, J_{3 \alpha .4}=2.0, J_{3 \beta, 4}=6.6\right), 6.87,6.94(\mathrm{AB} \mathrm{q}, 2 \mathrm{H}$, $\mathrm{H}-6$ and $\left.\mathrm{H}-7, J_{6.7}=8.7\right), 7.92\left(\mathrm{~d}, 1 \mathrm{H}, \mathrm{H}-1, J_{1.33}=2.7\right), 8.40(\mathrm{br} \mathrm{s}$, $1 \mathrm{H}, \mathrm{C} 8-\mathrm{OH}$, disappears with $\left.\mathrm{D}_{2} \mathrm{O}\right)$; ms: $234\left(0.5, \mathrm{M}^{++}\right), 216\left(100, \mathrm{M}^{++}\right.$ $-\mathrm{H}_{2} \mathrm{O}$ ), $201\left(84, \mathrm{M}^{++}-\mathrm{H}_{2} \mathrm{O}-\mathrm{CH}_{3}\right)$. Mol. Wt. (hrms) (base peak mass-matched), calcd. for $\mathrm{C}_{13} \mathrm{H}_{12} \mathrm{O}_{3}: 216.0786$; found: 216.0797.

$13 ; R_{\mathrm{r}} 0.3$; mp $199-200^{\circ} \mathrm{C}$ (methylene chloride); ir (KBr): 3200 (br), $1640,1615 \mathrm{~cm}^{-1}$; ${ }^{1} \mathrm{H} \mathrm{nmr:} 2.46\left(\mathrm{~s}, 3 \mathrm{H}, \mathrm{COCH}_{3}\right), 2.55$ (ddd, $1 \mathrm{H}$, $\left.\mathrm{H}-3 \beta, J_{g i m}=16.6, J_{3 \beta .4}=11.1, J_{1.33}=2.15\right), 3.1 \mathrm{I}(\mathrm{dd}, \mathrm{IH}, \mathrm{H}-3 \alpha$, $\left.J_{\mathrm{s} / m}=16.6, J_{3 \alpha, 4}=6.64\right), 3.84(\mathrm{~s}, 3 \mathrm{H}, \mathrm{OMe}), 5.38(\mathrm{dd}, 1 \mathrm{H}, \mathrm{H}-4$, after $\left.\mathrm{D}_{2} \mathrm{O}\right), 6.78,6.91\left(\mathrm{AB} \mathrm{q}, \mathrm{H}-6\right.$ and $\left.\mathrm{H}-7, J_{6.7}=9.0\right), 7.8 \mathrm{I}(\mathrm{d}, 1 \mathrm{H}$, $\left.\mathrm{H}-1, J_{1.33}=2.15\right), 7.92\left(\right.$ br s, $2 \mathrm{H}, 2 \times \mathrm{OH}$, exchanges with $\left.\mathrm{D}_{2} \mathrm{O}\right)$; ms: $234\left(2, \mathrm{M}^{++}\right) 0,216\left(100, \mathrm{M}^{++}-\mathrm{H}_{2} \mathrm{O}\right), 201\left(78, \mathrm{M}^{++}-\mathrm{H}_{2} \mathrm{O}-\right.$ $\mathrm{CH}_{3}$ ). Mol. Wt. (hrms) (base peak mass-matched), calcd. for $\mathrm{C}_{13} \mathrm{H}_{12} \mathrm{O}_{3}$ : 216.0786; found: 216.0789 .

\section{2-Acetyl-5-methoxy-8-hydroxynaphthalene 14}

The enone $12(25 \mathrm{mg})$ dissolved in chloroform was stirred vigorously with aqueous $2 N$ hydrochloric acid $(5 \mathrm{~mL})$ for $4 \mathrm{~h}$. The chloroform layer was separated, washed with water, dried $\left(\mathrm{Na}_{2} \mathrm{SO}_{4}\right)$, and the solvent removed. The residual solid was crystallized from ether (85\%); mp 155- $157^{\circ} \mathrm{C}$; ir (KBr): 3310 (br) $1660 \mathrm{~cm}^{-1}$; ${ }^{1} \mathrm{H} \mathrm{nmr}$ : $2.75\left(\mathrm{~s}, 3 \mathrm{H}, \mathrm{COCH}_{3}\right), 3.95(\mathrm{~s}, 3 \mathrm{H}, \mathrm{OMe}), 6.79(\mathrm{~s}, 2 \mathrm{H}, \mathrm{H}-6$ and $\mathrm{H}-7)$, $8.0\left(\mathrm{dd}, 1 \mathrm{H}, \mathrm{H}-3, J_{3.4}=9.0, J_{1.3}=1.76\right), 8.26\left(\mathrm{dd}, 1 \mathrm{H}, \mathrm{H}-4, J_{3.4}\right.$ $\left.=9.0, J_{1.4}=0.71\right), 8.82\left(\mathrm{dd}, 1 \mathrm{H}, \mathrm{H}-1, J_{1.3}=1.76, J_{1.4}=0.71\right)$; ms: $216\left(64, \mathrm{M}^{++}\right), 201\left(45, \mathrm{M}^{++}-\mathrm{CH}_{3}\right)$. Mol. Wt. (hrms) calcd. for $\mathrm{C}_{13} \mathrm{H}_{12} \mathrm{O}_{3}: 216.0786$; found: 216.0782 .

\section{2-Acetyl-5-hydroxy-8-methoxynaphthalene 15}

The enone $13(25 \mathrm{mg})$ treated with $2 \mathrm{~N} \mathrm{HCl}$ as above provided the naphthalene 15 which was crystallized from chloroform (85\%); mp $195-197^{\circ} \mathrm{C}$; ir $(\mathrm{KBr}): 3200 \mathrm{~cm}^{-1}$ (br), $1645 \mathrm{~cm}^{-1}$; ${ }^{1} \mathrm{H} \mathrm{nmr}$ (acetone$\left.d_{6}\right): 2.71\left(\mathrm{~s}, 3 \mathrm{H}, \mathrm{COCH}_{3}\right), 4.0(\mathrm{~s}, 3 \mathrm{H}, \mathrm{OMe}), 6.84,7.03(\mathrm{AB} \mathrm{q}, 2 \mathrm{H}$, $\mathrm{H}-6$ and $\left.\mathrm{H}-7, J_{6.7}=8.06\right), 8.0\left(\mathrm{dd}, 1 \mathrm{H}, \mathrm{H}-3, J_{3.4}=9.0, J_{1.3}=1.7\right)$, $8.26\left(\mathrm{~d}, \mid \mathrm{H}, \mathrm{H}-4, J_{3.4}=9.0\right), 8.82\left(\mathrm{~d}, 1 \mathrm{H}, \mathrm{H}-\mathrm{l}, J_{1.3}=1.7\right)$; ms: 216 $\left(100, \mathrm{M}^{++}\right), 201\left(84 \mathrm{M}^{++}-\mathrm{CH}_{3}\right)$. Mol. Wt. (hrms) calcd. for $\mathrm{C}_{13} \mathrm{H}_{12} \mathrm{O}_{3}: 216.0786$; found: 216.0791 .

\section{2,3-Methylenedioxy-5-methyl-6,7-dicarbomethoxy-8-hydroxynaph- thalene 18}

The dimethyl acetylene dicarboxylate adduct of 1-methyl-5,6-methylenedioxyisobenzofuran (3) $(0.21 \mathrm{~g})$ was refluxed in benzene $(15 \mathrm{~mL})$ with a few crystals of $p$-toluene sulfonic acid for $12 \mathrm{~h}$. The benzene solution was washed with dilute aqueous ammonia and the naphthol 18 extracted into aqueous sodium hydroxide. The alkaline extracts were combined, acidified with dilute hydrochloric acid, and extracted into methylene chloride. The organic extracts were washed with water, dried $\left(\mathrm{Na}_{2} \mathrm{SO}_{4}\right)$, and the methylene chloride removed. The residual solid was crystallized from ethanol (43\%); mp $185-186^{\circ} \mathrm{C}$; ${ }^{1} \mathrm{H}$ nmr: $2.4\left(\mathrm{~s}, 3 \mathrm{H}, \mathrm{CH}_{3}\right), 3.9\left(\mathrm{~s}, 6 \mathrm{H}, 2 \times \mathrm{CO}_{2} \mathrm{Me}\right), 6.08$ $\left(\mathrm{s}, 2 \mathrm{H}, \mathrm{OCH}_{2} \mathrm{O}\right), 7.19(\mathrm{~s}, 1 \mathrm{H}, \mathrm{H}-4), 7.67(\mathrm{~s}, 1 \mathrm{H}, \mathrm{H}-1), 12.0(\mathrm{~s}, 1 \mathrm{H}$, $\mathrm{OH})$; ms: $318\left(\mathrm{M}^{++}\right) 287\left(\mathrm{M}^{++}-\mathrm{OMe}\right)$. Mol. Wt. (hrms) calcd. for $\mathrm{C}_{16} \mathrm{H}_{14} \mathrm{O}_{7}$ : 318.0739 ; found: 318.0713 .

General procedure for the preparation of $\alpha$-naphthyl acetates

The naphthol dissolved in dry methylene chloride was treated with excess acetic anhydride and dimethylamino pyridine ( 1.5 equiv.) and stirred at room temperature for $4 \mathrm{~h}$. Water was added and stirring continued for a further $12 \mathrm{~h}$. The organic phase was separated, washed with aqueous sodium bicarbonate and water, the methylene chloride layer dried $\left(\mathrm{Na}_{2} \mathrm{SO}_{4}\right)$, and the solvent removed. Yields varied from $65-90 \%$.

\footnotetext{
${ }^{5}$ It is unlikely that the reverse-Michael reaction of the 10/11 mixture is responsible for the 3.5:1 ratio observed. An overall yield of $90 \%$ was obtained in this step and no selectivity or rearrangements had been encountered in a previous study of this reaction (ref. 4).
}

16; mp $119-\left.12\right|^{\circ} \mathrm{C}$ (methylene chloride); 'H nmr: 2.50 (s, $3 \mathrm{H}$, $\left.\mathrm{OCOCH}_{3}\right), 2.77\left(\mathrm{~s}, 3 \mathrm{H}, \mathrm{COCH}_{3}\right), 4.06\left(\mathrm{~s}, 3 \mathrm{H}, \mathrm{OCH}_{3}\right), 6.90$ and 7.23 $\left(\mathrm{AB} \mathrm{q}, 2 \mathrm{H}, \mathrm{H}-6\right.$ and $\left.\mathrm{H}-7, J_{6.7}=8.3\right), 8.04\left(\mathrm{dd}, 1 \mathrm{H}, \mathrm{H}-3, J_{3.4}=8.8\right.$, $\left.J_{1.3}=1.71\right), 8.34\left(\mathrm{~d}, 1 \mathrm{H}, \mathrm{H}-4, J_{3.4}=8.8\right), 8.41\left(\mathrm{~d}, 1 \mathrm{H}, \mathrm{H}-1, J_{1.3}=\right.$ 1.71); ms: $258\left(10, \mathrm{M}^{++}\right), 216\left(100, \mathrm{M}^{++}-\mathrm{CH}_{2} \mathrm{CO}\right), 201\left(46, \mathrm{M}^{++}\right.$ $\left.-\mathrm{CH}_{2} \mathrm{CO}-\mathrm{CH}_{3}\right)$

17; $\mathrm{mp} 151-152^{\circ} \mathrm{C}$ (methylene chloride); ${ }^{\prime} \mathrm{H} \mathrm{nmr}$ (acetone- $d_{6}$ ): $2.43\left(\mathrm{~s}, 3 \mathrm{H}, \mathrm{OCOCH}_{3}\right), 2.74\left(\mathrm{~s}, 3 \mathrm{H}, \mathrm{COCH}_{3}\right), 4.10\left(\mathrm{~s}, 3 \mathrm{H}, \mathrm{OCH}_{3}\right)$, 7.03 and 7.35 (AB q, $2 \mathrm{H}, \mathrm{H}-6$ and $\mathrm{H}-7, J_{6.7}=8.3$ ), $7.94(\mathrm{~d}, \mathrm{lH}, \mathrm{H}-4$, $\left.J_{3.4}=9.03\right), 8.09\left(\mathrm{dd}, 1 \mathrm{H}, \mathrm{H}-3, J_{3.4}=9.03, J_{1.3}=1.46\right), 8.9(\mathrm{~d}, 1 \mathrm{H}$, $\left.\mathrm{H}-1, J_{1.3}=1.46\right)$; ms: $258\left(23, \mathrm{M}^{*+}\right), 216\left(\mathrm{I00}, \mathrm{M}^{*+}-\mathrm{CH}_{2} \mathrm{O}\right), 20 \mathrm{I}$ $\left(89, \mathrm{M}^{\cdot+}-\mathrm{CH}_{2} \mathrm{CO}-\mathrm{CH}_{3}\right)$.

19; mp $165^{\circ} \mathrm{C}$ (methylene chloride); ' $\mathrm{H} \mathrm{nmr}$. $2.4\left(3 \mathrm{H}, \mathrm{CH}_{3}\right), 2.6(\mathrm{~s}$, $\left.3 \mathrm{H}, \mathrm{OCOCH}_{3}\right), 3.88$ and $3.92\left(\mathrm{~s}, 3 \mathrm{H}\right.$ each, $\left.2 \times \mathrm{CO}_{2} \mathrm{Me}\right), 6.12(\mathrm{~s}, 2 \mathrm{H}$, $\left.\mathrm{OCH}_{2} \mathrm{O}\right), 7.18(\mathrm{~s}, 1 \mathrm{H}, \mathrm{H}-4), 7.37(\mathrm{~s}, 1 \mathrm{H}, \mathrm{H}-\mathrm{I})$; ms: $360\left(6, \mathrm{M}^{-+}\right) 318$ $\left(56, \mathrm{M}^{++}-\mathrm{CH}_{2} \mathrm{CO}\right), 2.86\left(100, \mathrm{M}^{-+}-\mathrm{CH}_{2} \mathrm{CO}-\mathrm{MeOH}\right)$.

21; mp $180-181^{\circ} \mathrm{C}$ (methylene chloride - ethyl acetate); ' $\mathrm{H} \mathrm{nmr}$ : $7.22(\mathrm{~s}, 1 \mathrm{H}, \mathrm{H}-1), 6.94(\mathrm{~s} ; 1 \mathrm{H}, \mathrm{H}-4)$; ms: $512\left(23, \mathrm{M}^{*+}\right), 470\left(63, \mathrm{M}^{*+}\right.$ $-\mathrm{CH}_{2} \mathrm{CO}$ ).

23; mp 216-217 ${ }^{\circ} \mathrm{C}$ (methylene chloride); ' $\mathrm{H} \mathrm{nmr}$ : 7.21 (s, $1 \mathrm{H}$, $\mathrm{H}-1), 6.92(\mathrm{~s}, \mathrm{IH}, \mathrm{H}-4)$; $\mathrm{ms}: 482\left(17, \mathrm{M}^{++}\right), 440\left(61, \mathrm{M}^{++}-\mathrm{CH}_{2} \mathrm{CO}\right)$. 25; mp 213-214 ${ }^{\circ} \mathrm{C}$ (methylene chloride - ethyl acetate); ${ }^{1} \mathrm{H}$ nmr: $7.21(\mathrm{~s}, 1 \mathrm{H}, \mathrm{H}-1), 6.90(\mathrm{~s}, 1 \mathrm{H}, \mathrm{H}-4)$; ms: $466\left(13, \mathrm{M}^{++}\right), 424\left(50, \mathrm{M}^{++}\right.$

$-\mathrm{CH}_{2} \mathrm{CO}$ ).

27; $\mathrm{mp} 184-185^{\circ} \mathrm{C}$ (methylene chloride - ethyl acetate); ' $\mathrm{H} \mathrm{nmr}$ : $7.16(\mathrm{~s}, 1 \mathrm{H}, \mathrm{H}-1), 6.89(\mathrm{~s}, \mathrm{JH}, \mathrm{H}-4)$; ms: $482\left(13, \mathrm{M}^{++}\right), 440\left(52, \mathrm{M}^{-+}\right.$ $\left.-\mathrm{CH}_{2} \mathrm{CO}\right)$.

\section{Acknowledgement}

We thank the Natural Sciences and Engineering Research Council of Canada for support of this work.

1. B. A. KeAY and R. Rodrigo. Can. J. Chem. 61, 637 (1983); Tetrahedron, 40, 4597 (1984).

2. F. ARCAMONE. Doxorubicin anticancer antibiotics. Medicinal chemistry. Vol. 17. Academic Press, New York. 1981; H. S. EL KHADEM (Editor). Anthracycline antibiotics. Academic Press, New York. 1982.

3. B. A. Keay, H. P. Plaumann, D. Rajapaksa, and R. Rodrigo. Can. J. Chem. 61, 1987 (1983)

4. B. A. Keay, D. Rajapaksa, and R. Rodrigo. Can. J. Chem. 62, 1093 (1984).

5. J. M. MCNamara and Y. Kishi. J. Am. Chem. Soc. 104, 7371 (1982).

6. J-P. Gesson and M. Mondon. J. Chem. Soc. Chem. Commun. 421 (1982); M. SEKIZAKI, M. JUNG, J. M. MCNAMARA, and Y. KisHI. J. Am. Chem. Soc. 104, 7372 (1982).

7. R. J. HigheT and P. F. HigheT. J. Org. Chem. 30, 902 (1965).

8. H. P. Plaumann, J. G. Smith, and R. Rodrigo. J. Chem. Soc. Chem. Commun. 354 (1980).

9. J. G. RodrigueZ, J. VIlches, P. SMITH-VERdiER, and S. GARCia-BlanCO. Tetrahedron, 39, 199 (1983).

10. W. B. SMith, D. L. Deavenport, and A. M. Ihrig. J. Am. Chem. Soc. 94, 1959 (1972).

11. R. H. F. MANSke, R. RodRigo, D, B. Maclean, and L. BaCZYNSKJ. Quimica, 68, 689 (1972).

12. C. K. YU, D. B. MACLEAN, R. RODRIGO, and R. H. F. MANSKE. Can. J. Chem. 48, 3673 (1970).

13. J. W. EMSLEy, J. C. Lindon, S. R. Salman, and D. T. Clark. J. Chem. Soc. Perkin Trans. 2, 611 (1973).

14. M. Am. Makhlouf and B. Rickborn. J. Org. Chem. 46, 2734 (1981); R. N. WARRENER, B. C. HAMER, and R. A. RusSEll. J. Chem. Soc. Chem. Commun. 942 (1981); L. Contreras and D. B. Maclean. Can. J. Chem. 58, 2573 (1980); J. G. SMith, S. S. Welankiwar, B. S. Shantz, E. H. Lai, and N. G. ChU. J. Org. Chem. 45, 1817 (1980).

15. A. S. Kende, D. P. Curran, Y, G. TSay, and J. E. Mills. Tetrahedron Lett. 3537 (1977). 